\section{Early days of behaviourism}

\section{O.L. Zangwill}

J.B. Watson: The Founder of Behaviourism. By David Cohen. Pp. 297. (Routledge and Kegan Paul: London and Boston, 1979.) $£ 8.95$.

THIS is a biography of Watson; not a study of the origins of behaviourism. Nonetheless, Dr Cohen's well researched and highly readable book tells us a good deal about the early days of behaviourism, a school of psychology which Watson himself once spoke of with evident pride as "this purely American production". His account will do much to demolish the still popular myth that behaviourism amounted to little more than the export of conditioned reflexes from Russia to the United States and the substitution of muscle twitches for mind as the subject-matter of psychology. At all events, in so far as conditioned reflexes are concerned, Watson owed distinctly less to Pavlov than to his contemporary and rival, Vladimir Bechterev, whose correspondence with Watson may still be seen at the Bechterev Institute in Leningrad. Moreover, Pavlov himself made no secret of his detestation of behaviourism and ridiculed its pretensions to be a scientific discipline. Pavlov, of course, was a militant physiologist imbued with the materialist philosophy which he had brought from Germany, whereas Watson was a psychologist through and through, concerned only to establish a viable science of human behaviour. It is not surprising that relations between them were cool.

John Broadus Watson was born in 1878 in Greenville, South Carolina. His father was an impecunious farmer and his mother a pillar of the local Baptist community and a Fundamentalist who evidently ruled her family with a rod of iron. Following graduation from Furman University in 1899, Watson proceeded to the University of Chicago, where he came strongly under the influence of James Rowland Angell, a sometime student of William James' who favoured a biological, or as it was then termed 'functionalist', approach to psychology in contrast to the 'structuralist' approach of Wundt, with its emphasis on classification and introspective method, which Titchener and other early experimental psychologists had exported from Germany. Although Watson came later to disown 'functionalism' almost as radically as 'structuralism', he seems to have retained towards Angell himself a deep and abiding respect.

On Angell's advice, Watson began his graduate work in the field of comparative psychology. His PhD thesis, published in 1903 as a monograph under the title of
Animal Intelligence, was largely concerned with the growth of learning capacity in the white rat, with special reference to the medullation of the nervous system. (The neurological aspects of this work owed much to the Chicago neuroanatomist, H.H. Donaldson, who evidently thought highly of Watson and to whose personal generosity he owed its publication.) In this study, it is noteworthy that Watson had no hesitation in using the concepts and nomenclature of introspective psychology, and it belongs much more closely within the 'functionalist' tradition than any of Watson's later publications.

Watson continued with his animal work at Chicago for several years and some of it has proved surprisingly durable. With Harvey Carr, he worked on spatial orientation in the rat, with special reference to kinaesthesis and the sensory control of maze learning. At this time, too, he first made the acquaintance of Karl Lashley, then still a graduate student, and collaborated with him in some early studies of bird behaviour. He also came to know Robert Yerkes, then a young physiologist at Yale, who became a firm colleague and friend. From Dr Cohen's account, it might be surmised that, had Watson-remained in Chicago, it is by no means impossible that the scandal which was later to drive him out of academic life would have been averted.

In 1908, Watson became a full Professor of Psychology at Johns Hopkins University, and it was at Baltimore that behaviourism was born. No doubt the sympathetic biological climate of this University, and more especially its Medical School, contributed to this happy event, but by far the most important determinant was the advent of Lashley as a PhD student in zoology and psychology in 1911. Although Watson's background in animal psychology and, above all, his total disillusionment with the current schools of experimental psychology, no doubt touched off the behaviourist revolution, without Lashley it seems unlikely that behaviourism would have evolved as a credible competitor or achieved a measure

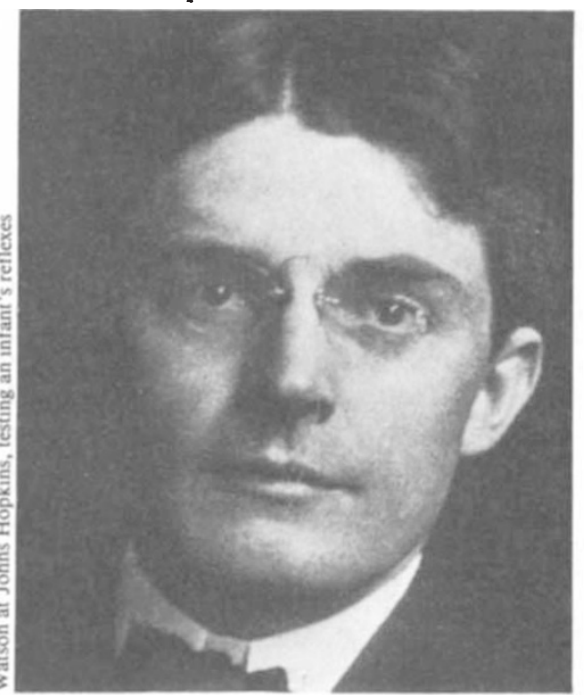

of real scientific distinction. It was these two men working in close association who virtually created the behaviourist movement.

What, then, was the behaviourist position? This Dr Cohen outlines in two substantial chapters, adequate though philosophically less sophisticated than the account given by Dr B.D. Mackenzie in his recent book on Behaviourism and the Limits of Scientific Method (Routledge and Kegan Paul: London, 1977). It may be briefly summarised as follows. First, Watson had already proclaimed that psychology is (or should be) "a purely experimental branch of natural science whose theoretical goal is the prediction and control of human behaviour". There seems little doubt that Lashley was fully in accord with this view. Secondly, both men insisted that introspection, for so long viewed as indispensable to the analysis of mind, has no place in behaviourist psychology; nor is the value of its data dependent "on the readiness with which they lend themselves to interpretation in terms of consciousness". Lashley later devoted two important papers to justifying this contention. Thirdly, behaviourism was in keeping with traditional Darwinism in so far as it recognised no sharp distinction between the behaviour of animals and that of man. At the same time, it must be borne in mind that, despite the preoccupation with animal behaviour which seemed almost to obsess the behaviourists, it was the understanding of human behaviour which Watson came increasingly to regard as the primary objective of psychological science.

In his seven years at Johns Hopkins, Watson was somewhat less active in personal research but successful in building up a Department of high standing in its field. He was particularly interested in developing detailed observational study of the development of behaviour in young children, particularly their emotional reactions, in connection with which he drew inspiration not only from Pavlov but, more surprisingly, from Freud, whose observations on infantile sexuality par-

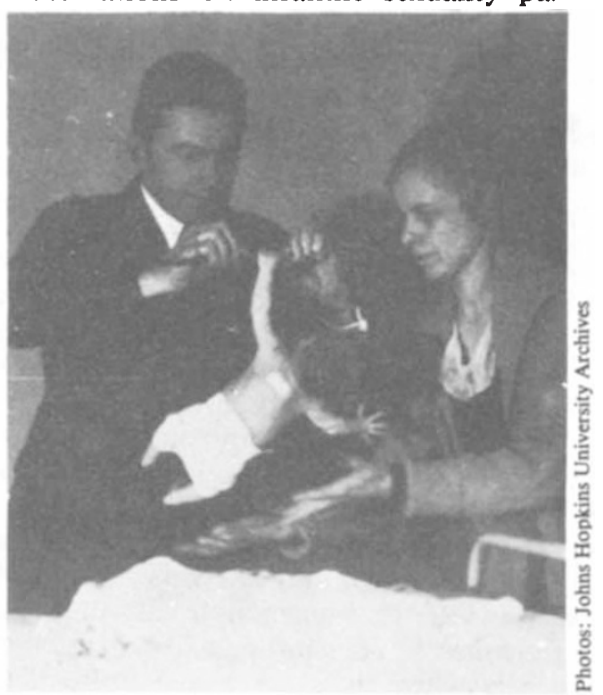


ticularly impressed him. Much of this work was carried out by his graduate students, one of whom was Rosalie Rayner, later his second wife, and some of their work was reported in Psychology from the Standpoint of a Behaviourist (1919), by far Watson's best book. It is odd that an important paper on conditioned emotional reactions in children, written in collaboration with Rayner, is not cited in Watson' bibliography as given in the present book.

In 1920 , Watson featured in a divorce case which brought him considerable notoriety and entailed his enforced resignation from his Professorship. The whole sorry story and its attendant circumstances are fully described by $\mathrm{Dr}$ Cohen and it is of some interest to note that E.B. Titchener, a conservative Englishman who for many years represented the Wundtian tradition in America and who had no use whatsoever for behaviourism, was one of the very few professional colleagues who stood by Watson after his fall from grace. In spite of Titchener's support, however, Watson was never again offered a University post and resigned himself to a career in advertising, in which, however, he seems to have been strikingly successful. He also wrote a number of popular articles concerned with child upbringing and education, some of which won the approval of Bertrand Russell, who had himself experienced academic rejection at first hand and was no stranger to the devastating smugness of many American academic institutions some fifty years ago.

The only serious scientific work which continued to engage Watson after his resignation from Johns Hopkins was his observational work on young children. Although much of this was undertaken by a devoted co-worker, Mary Cover Jones, the ideas were undoubtedly Watson's and the work resulted in several interesting, if desultory, publications. Today, this work is of interest largely as the forerunner of what has come to be known as behaviour therapy, which has become a major industry in clinical psychology. Watson, however, did no more than adumbrate the theory and methods of behaviour therapy; its systematic development is the work of others more recent.

Had Watson remained active in psychology, one may hazard the guess that behaviourism would have run a very different, and perhaps more fertile, course. In particular, the obsession with learning theory which infected American psychology in the 1940s and 1950s, and in attenuated form is still with us today, might have proved altogether less dispiriting. On the other hand, the neurological element in Watson's thinking, later developed with such distinction by Karl Lashley, might well have taken earlier and firmer root in American psychology. The advent of behaviour therapy, too, might well have taken place sooner, and been less

disfigured by empty 'scientism' and doctrinaire rejection of Freud and all his works. Finally, a tradition of research on human development might have grown up in America well before Piaget became the monolithic institution that he is today. As a "purely American production", Watson's behaviourism had a genuine feel for biology and a healthy freshness and enter-

\section{Skinnerian behaviour}

\section{Stuart Sutherland}

The Shaping of a Behaviorist. By B. F. Skinner. Pp. 373. (Alfred A. Knopf; New York, 1979.) \$12.95.

To the general public B. F. Skinner is perhaps the best known experimental psychologist. He has attained fame by repeatedly asseverating the principle that all behaviour is governed by reinforcement, and by his sinister but well intentioned suggestion that we should engineer everyone's environment from birth to produce desirable behaviour. The second volume of his autobiography, The Shaping of a Behaviorist, describes his life between the ages of 26 , when he entered graduate school at Harvard, and 45, when he became a Harvard professor. The title is misleading: the book in fact fails to reveal the schedule of reinforcement that deflected the young Skinner from his interest in English literature and turned him into a Behaviourist so extreme that he denied the existence of mental events. Unfortunately he abides by his own precepts, and gives no hint either of his own feelings and emotions or of those which actuated the numerous colleagues, acquaintances and girl friends who appear in these pages. In consequence, the book resembles a set of scientific protocols in which events are meticulously recorded but all speculation about cause and effect is avoided.

Skinner's professional success is in part due to his capacity for disciplining himself and for making the utmost use of his talents. He seems rarely to have had an idea that did not eventually appear in print: his book on verbal behaviour was planned ten years before it was written. His substitute for prayer was to write stern notes to himself: when he was thirty he prepared a document entitled "Plan of the Campaign for the Years 30-60" which ends with the frank acknowledgement "Plan for the Years $60-(?)$. These are beyond my present control". To explain how such elaborate exercises in planned self-control are learned would be a nice challenge to his own theory.

The period of his life described was by prise in tackling the problems of experiment in the sphere of mind. Like many other American products, unfortunately, Watsonian behaviourism failed to survive the Depression.

O.L. Zangwill is Professor of Experimental Psychology in the University of Cambridge, UK.

no means an easy one. It is true that he gained a prestigious Junior Fellowship at Harvard, but finding academic positions in the Depression was difficult and he was forced to exile himself to the University of Minnesota and subsequently to Indiana before returning triumphantly as a full professor to Harvard in 1948. During the War he attempted to train pigeons to guide a missile on to its target, but the idea was never taken up by the military authorities. He brought his second daughter up in a specially designed crib, but his attempts to market the "Heir Conditioner" were unsuccessful. Moreover, much of his early work on animal learning met with little acclaim and was overshadowed by the grandiose theorising of Hull and Tolman.

From an early age Skinner set himself against theorising: he was interested only in finding some behaviour that would vary in a quantitative way with changes in the controlling factors. For him the discovery of such a lawful relationship was enough, and he showed little concern over the novelty or importance of his findings: indeed in the absence of a theory, there can be no criteria for what is an important finding.

Nor did Skinner open up any

\section{Sorry, for copyright \\ reasons some images on this page may not be available online}

